\title{
Bank Concentration, Competition, and Crises: First results
}

\author{
Thorsten Beck, Asli Demirgüç-Kunt and Ross Levine
}

First Draft: December, 2002

This Draft: May 2005

\begin{abstract}
Motivated by public policy debates about bank consolidation and conflicting theoretical predictions about the relationship between bank concentration, bank competition and banking system fragility, this paper studies the impact of national bank concentration, bank regulations, and national institutions on the likelihood of a country suffering a systemic banking crisis. Using data on 69 countries from 1980 to 1997, we find that crises are less likely in economies with more concentrated banking systems even after controlling for differences in commercial bank regulatory policies, national institutions affecting competition, macroeconomic conditions, and shocks to the economy. Furthermore, the data indicate that regulatory policies and institutions that thwart competition are associated with greater banking system fragility.
\end{abstract}

Keywords: Banking System Fragility, Industrial Structure, Regulation

JEL Classification: G21, G28, L16

Beck and Demirgüç-Kunt: World Bank; Levine: Carlson School of Management, University of Minnesota and the NBER. We thank two anonymous referees, John Boyd, Jerry Caprio, Maria Carkovic, Patrick Honohan and participants in the World Bank Concentration and Competition Conference for comments and Paramjit K. Gill, Lin $\mathrm{Li}$ and April Knill for outstanding research assistance. This paper's findings, interpretations, and conclusions are entirely those of the authors and do not necessarily represent the views of the World Bank, its Executive Directors, or the countries they represent. 


\section{Introduction}

The consolidation of banks around the globe is fueling an active public policy debate on the impact of consolidation on financial stability. ${ }^{1}$ Indeed, economic theory provides conflicting predictions about the relationship between the concentration and the competitiveness of the banking industry and banking system fragility. Motivated by public policy debates and ambiguous theoretical predictions, this paper investigates empirically the impact of bank concentration and bank regulations on banking system stability.

Some theoretical arguments and country comparisons suggest that a less concentrated banking sector with many banks is more prone to financial crises than a concentrated banking sector with a few banks (Allen and Gale, 2000, 2004). First, concentrated banking systems may enhance market power and boost bank profits. High profits provide a "buffer" against adverse shocks and increase the charter or franchise value of the bank, reducing incentives for bank owners and managers to take excessive risk and thus reducing the probability of systemic banking distress (Hellmann, Murdoch, and Stiglitz, 2000; Besanko and Thakor, 1993; Boot and Greenbaum, 1993, Matutes and Vives, 2000). ${ }^{2}$ Second, some hold that it is substantially easier to monitor a few banks in a concentrated banking system than it is to monitor lots of banks in a diffuse banking system. From this perspective, supervision of banks will be more effective and the risks of contagion and thus systemic crisis less pronounced in a concentrated banking system. According to Allen and Gale (2000), the U.S., with its large number of banks, supports this

\footnotetext{
${ }^{1}$ See Group of Ten (2001), Bank for International Settlements (2001), International Monetary Fund (2001). See Carletti and Hartmann (2003) and Boyd and De Nicoló (2005) for an overview of the literature.

${ }^{2}$ Rather than focusing on the links between concentration and the portfolio decisions of banks, Smith (1984) holds banks' asset allocation decisions constant and examines the liquidity side of the balance sheet. He shows that less competition can lead to more stability if information about the probability distribution of depositors' liquidity needs
} 
"concentration-stability" view since it has had a history of much greater financial instability than the U.K or Canada, where the banking sector is dominated by fewer larger banks. ${ }^{3}$

An opposing view is that a more concentrated banking structure enhances bank fragility. First, Boyd and De Nicolo (2005) argue that the standard argument that market power in banking boosts profits and hence bank stability ignores the potential impact of banks' market power on firm behavior. They confirm that concentrated banking systems enhance market power, which allows banks to boost the interest rate they charge to firms. Boyd and De Nicolo's (2005) theoretical model, however, shows that these higher interest rates may induce firms to assume greater risk. Thus, in many parameterizations of the model, Boyd, and De Nicolo (2005) find a positive relationship between concentration and bank fragility and thus the probability of systemic distress. Similarly, Caminal and Matutes (2002) show that less competition can lead to less credit rationing, larger loans and higher probability of failure if loans are subject to multiplicative uncertainty. Second, advocates of the "concentration-fragility" view argue that (i) relative to diffuse banking systems, concentrated banking systems generally have fewer banks and (ii) policymakers are more concerned about bank failures when there are only a few banks.

is private. Matutes and Vives (1996), however, highlight the complexity of the linkages running from market structure, to competition, to bank stability and show that bank fragility can arise in any market structure.

${ }^{3}$ Some proponents of the "concentration-stability" view argue that -- holding other things constant - (i) banks in concentrated systems will be larger than banks in more diffuse systems and (ii) larger banks tend to be better diversified than smaller banks. Based on these assumptions, concentrated banking systems with a few large banks will be less fragile than banking systems with many small banks. Models by Diamond (1984), Ramakrishnan and Thakor (1984), Boyd and Prescott (1986), Williamson (1986), Allen (1990), and others predict economies of scale in intermediation. As discussed by Calomiris (2000) and Calomiris and Mason (2000), an extensive literature finds an inverse relationship between bank scale and bank failure in the United States. However, empirical work by Chong (1991) and Hughes and Mester (1998) indicates that bank consolidation tends to increase the riskiness of bank portfolios. Boyd and Runkle (1993), examining 122 U.S. bank holding companies, find that there is an inverse relationship between size and the volatility of asset returns, but no evidence that large banks are less likely to fail. De Nicoló (2000), on the other hand, finds a positive and significant relationship between bank size and the probability of failure for banks in the U.S., Japan and several European countries. Further, in a concentrated banking system, the contagion risk of a single bank failure could be more severe, resulting in a positive link between concentration and systemic fragility. Thus, there are open issues regarding the relationship between bank size and bank risk. Although we explore the sensitivity of our results to controlling for the mean bank size in each country, this paper examines the relationship between bank concentration, bank regulations, and crises, not the relationship between bank size and diversification. 
Based on these assumptions, banks in concentrated systems will tend to receive larger subsidies through implicit "too important to fail" policies that intensify risk-taking incentives and hence increase banking system fragility (e.g., Mishkin, 1999)., 5

Despite conflicting theoretical predictions and policy debates, there is no cross-country empirical evidence on bank concentration, bank competition and the incidence of systemic banking failures. For the U.S., Keeley (1990) provides evidence that increased competition following relaxation of state branching restrictions in the 1980s resulted in an increase in large banks' risk profiles. Jayaratne and Strahan (1998), on the other hand, find that deregulation in the 1980s resulted in lower loan losses, while Dick (2003) finds higher loan loss provisions following deregulation in the 1990s. On the cross-country level, De Nicoló et al. (2003) relate bank concentration to the fragility of the largest five banks in a country and find a positive relationship, suggesting that bank concentration leads to more bank fragility. They do not consider the incidence of systemic banking distress.

Using data on 69 countries over the period 1980-1997, this paper provides the first crosscountry assessment of the impact of national bank concentration, bank regulations, and national

\footnotetext{
${ }^{4}$ There is a literature that examines deposit insurance and its effect on bank decisions. According to this literature (e.g. Merton (1977), Sharpe (1978), Flannery (1989), Kane (1989), Keeley (1990), Chan, Greenbaum and Thakor (1992), Matutes and Vives (2000) and Cordella and Yeyati (2002)) - mis-priced deposit insurance produces an incentive for banks to take risk. If the regulatory treatment were the same for insured banks of all sizes, these models would predict no relationship between bank size and riskiness. Since regulators fear potential macroeconomic consequences of large bank failures, most countries have implicit "too large to fail" policies which protect all liabilities of very large banks whether they are insured or not. Thus, the largest banks frequently receive a greater net subsidy from the government (O'Hara and Shaw, 1990). Even in the absence of deposit insurance, banks are prone to excessive risk-taking due to limited liability for their equity holders and to their high leverage (Stiglitz, 1972). This subsidy may in turn increase the risk-taking incentives of the larger banks. For an analysis of the corporate governance of banks, see Macey and O'Hara (2003).

${ }^{5}$ Proponents of the concentration-fragility view would also disagree with the proposition that a concentrated banking system characterized by a few banks is easier to monitor than a less concentrated banking system with many banks. The countervailing argument is as follows. Bank size is positively correlated with complexity so that large banks are harder to monitor than small banks. Holding all other features of the economy constant, concentrated banking systems tend to have larger banks. Thus, this argument predicts a positive relationship between concentration and fragility. Again, this paper focuses on the aggregate relationship between bank concentration and crises. Although we control for bank size in our regressions, we do not examine the linkages between bank size and the ease of monitoring.
} 
institutions on the likelihood of a country suffering a systemic banking crisis. ${ }^{6}$ While defined more rigorously below, a systemic banking crisis refers to an episode when the entire national banking system has suffered sufficient losses such that non-performing loans exceed ten percent of total banking system assets, or when the government has taken extraordinary steps, such as declaring a bank holiday or nationalizing much of the banking system. Besides the relationship between systemic banking crises and concentration, we also examine international differences in bank capital regulations, rules restricting bank entry, regulatory restrictions on bank activities, and the overall institutional environment. While we use cross-country differences in these bank regulations and institutions to assess the robustness of the relationship between concentration and crises, the results on regulations and institutions are independently valuable. Specifically, we provide empirical evidence on which regulations and institutions are associated with bank stability.

The bulk of the evidence indicates that crises are less likely in more concentrated banking systems, which supports the concentration-stability view. The negative relationship between concentration and crises holds when conditioning on macroeconomic, financial, regulatory, institutional, and cultural characteristics and is robust to an array of sensitivity checks. The data never support the concentration-fragility view. Furthermore, our analyses suggest that the relationship between concentration and crises is not driven by reverse causality. While we cannot confirm or reject these results when restricting our sample to the high-income countries not surprising given the limited number of countries and crises - the significant, negative

\footnotetext{
${ }^{6}$ Demirgüç-Kunt, Laeven and Levine (2004) investigate the impact of bank concentration and regulations on bank net interest margins, but they do not examine bank fragility. Earlier work on systemic banking instability has mostly focused on identifying (i) the macroeconomic determinants of banking crises (Gonzalez-Hermosillo, et al., 1997; Demirgüç-Kunt and Detragiache, 1998, henceforth DD), (ii) the relationship between banking and currency crises (Kaminsky and Reinhart, 1999), (iii) the impact of financial liberalization on bank stability (DD, 1999), and (iv) the impact of deposit insurance design on bank fragility (DD, 2002). Barth et al. (2004) examine the relationship between bank regulations and crises, but they do not examine bank concentration.
} 
relationship between concentration and banking system fragility holds for the sub-sample of developing countries.

The data also indicate that (i) fewer regulatory restrictions on banks - lower barriers to bank entry and fewer restrictions on bank activities - reduce banking system fragility, and (ii) countries with national institutions that facilitate competition in general have a lower likelihood of suffering a systemic banking crisis. Thus, more competitive banking systems are associated with less banking system fragility. In terms of linking the results back to specific parts of the concentration-stability view, the finding that competition reduces fragility when controlling for concentration suggests that something else besides a positive relationship between bank concentration and bank profits drives the negative relationship between bank concentration and banking system fragility. Our results also suggest that concentration might be an insufficient measure of the competitiveness of the banking system. ${ }^{7}$

Given that this is an initial study of bank concentration and crises, these results must be qualified along a number of dimensions. First, we investigate systemic banking crises, which are very difficult to define and date. Consequently, we use different definitions of and dates for crises and obtain robust results. Nevertheless, future work that assesses the impact of the market structure of the banking industry and bank regulations on individual bank fragility will provide a valuable complement to and extension of our research. Second, in some specifications, we examine cross-country differences in bank regulatory policies and national institutions to (i) assess the robustness of the concentration-fragility relationship and (ii) provide information on the links between bank regulations, national institutions, and banking system crises. We are cautious about these results, however, because the regulatory and institutional indicators are

\footnotetext{
${ }^{7}$ See also Claessens and Laeven (2004) who do not find any evidence for a negative relationship between bank concentration and a measure of bank competitiveness calculated from marginal bank behavior.
} 
measured toward the end of the sample period. Thus, the regulatory and institutional variables are measured after some of the crises. This timing problem does not affect our primary results on bank concentration because the same results hold when these regulatory variables are excluded. Furthermore, some existing research that we review below finds that, except in a few countries, regulatory policies and national institutions have, in general, changed little over the last couple of decades. Nevertheless, future work that focuses on bank-level fragility while using detailed data on bank regulations and institutions will further contribute to our understanding of the determinants of banking crises. Third, this paper provides evidence that is consistent with concentration-stability theories, but inconsistent with models that emphasize the concentrationfragility view. Nonetheless, the empirical work does not explain exactly why concentration increases banking system stability. Future work needs to more fully dissect the channels through which concentration influences bank stability. Finally, while policy-relevant, this research provides an initial assessment of whether concentration is positively or negatively associated with crises and should not be taken as a recommendation for greater bank concentration.

The rest of the paper is organized as follows. Section II describes the data set and presents summary statistics. Section III explains the methodology used in empirical tests. Section IV contains the main results and Section V concludes. 


\section{Data and Summary Statistics}

Our sample covers the period $1980-1997 .{ }^{8}$ Table 1 presents descriptive statistics for the whole sample. ${ }^{9}$

Crisis is a dummy variable that equals one if the country is going through a systemic crisis and zero if it is not. We use the Demirgüç-Kunt and Detragiache (2002, henceforth DD) dating of systemic banking crises, referring to periods where the national banking system is in such distress that it is not capable of fulfilling any meaningful intermediation role for the economy. Using country-specific data on individual bank failures and reports by national supervisory agencies, along with data collected by Lindgren, Garcia and Saal (1996) and Caprio and Klingebiel (1999), DD (2002) define systemic banking crises as occurring when emergency measures were taken to assist the banking system (such as bank holidays, deposit freezes, blanket guarantees to depositors or other bank creditors), or if large-scale nationalizations took place. DD (2002) also classify a country as experiencing a systemic banking crisis if non-performing assets reached at least 10 percent of total assets at the peak of the crisis, or if the fiscal cost of the rescue operations was at least 2 percent of GDP. Many crises run for multiple years. Following DD (2002), we exclude years classified as crisis years after the initial year of the crisis because during a crisis, the behavior of some of the explanatory variables is likely to be affected by the crisis itself. Note, however, that including all of the crisis years does not change the conclusions, as we demonstrate in the tables below. For the period 1980-1997, our sample includes 69 countries and 47 crisis episodes. Besides using this definition of systemic crises, which has

\footnotetext{
${ }^{8}$ The data include the East Asian crises, but are robust to their exclusion.

${ }^{9}$ Appendix Tables 1 and 3 (i) provide data sources, (ii) present country data on GDP per capita, concentration, crisis periods, and (iii) define the rationale for classifying each crisis as a systemic banking crisis. Appendix Table 2 presents separate statistics for crisis- and non-crisis observations. These tables are available on request.
} 
been employed by recently published papers (DD, 1998, 2002; Barth et al, 2004, 2005), we provide robustness tests using alternative definitions of "systemic crises." 10

Concentration equals the share of assets of the three largest banks in total banking system assets. ${ }^{11}$ We compute a measure of bank concentration using the Bankscope database compiled by Fitch-IBCA, which reports bank balance sheet data in a large cross-section of countries beginning in 1988. Since the sample of banks covered in Bankscope increased over the sample period, changes in the concentration measure could reflect changes in coverage. To reduce biases stemming from the coverage problem, we average the concentration measure over the period 1988-1997. Moreover, other information suggests that changes in Bankscope coverage do not influence our results because we obtain the same results using (i) annual concentration values, (ii) concentration from Bankscope measured at the beginning of the sample period, and (iii) different measures of concentration. Furthermore, by confirming our results using the initial level of concentration at the start of the sample period, we reduce reverse causality concerns.

As reported in Table 1, there is wide cross-country variation in the sample, with concentration levels ranging from less than 20 percent for the U.S. to 100 percent for many African countries, with a sample mean of $71 \%$.

We control for many factors. Specifically, we begin with the econometric specification in DD (2002) and include the same regressors. Thus, we include the rate of growth of real GDP, the change in the external terms of trade, and the rate of inflation, to capture macroeconomic developments that are likely to affect the quality of bank assets. The short-term real interest rate

\footnotetext{
${ }^{10}$ While recognizing that there is no single, unanimous definition of a systemic banking crisis, the primary goal of this paper is to provide the first cross-country assessment of the relationship between bank concentration, competition, and crises. Thus, we assess this link using different definitions of both crises and concentration. ${ }^{11}$ Defining the economy as the relevant banking market abstracts from the fact that in some developed countries, such as the United States, the relevant banking market is sub-national. Below, we control for this fact by testing the robustness of our results to dropping developed economies.
} 
is included to capture the banks' cost of funds. Also, higher real interest rates may affect bank profitability increasing default rates. The vulnerability of the banking system to sudden capital outflows triggered by foreign exchange risk is measured by the rate of exchange rate depreciation and by the ratio of M2 to foreign exchange reserves. Lagged credit growth is also a control since high rates of credit expansion may finance an asset price bubble that may cause a crisis when it bursts. We also include DD's (2002) index of moral hazard caused by deposit insurance generosity since they find that it contributes significantly to financial fragility. ${ }^{12}$ Finally, GDP per capita is used to control for the level of development of the country. Table 1 shows a wide variation in the control variables across countries and over time. Our preliminary analyses show that countries in crisis grow more slowly, experience negative terms of trade shocks, and have both higher inflation and deprecation rates than countries not in crisis. ${ }^{13}$

We also augment the benchmark specification in DD by using measures of bank regulation, the competitiveness of the banking system and the economy in general, and a summary institutional index. Including these measures allows us to test for the direct effect of competitiveness on systemic crisis probability, controlling for banking sector concentration. Measures of bank regulation come from Barth et al., (2001, 2004, 2005). The data set is collected through surveys of government officials in the late 1990s. There is some evidence, however, that regulatory policies have not changed much in most countries. For instance, Barth et al. (2001) show that the regulatory restrictions on bank activities did not change much following systemic crises. Moreover, in the few cases when they did change, there was a change

\footnotetext{
${ }^{12}$ To build an aggregate index of moral hazard, DD (2002) estimate the first principal component of various deposit insurance design features. Specifically, they use coinsurance, coverage of foreign currency and interbank deposits, type of funding, source of funding, management, membership, and the level of explicit coverage to create this aggregate index that increases with the generosity of the deposit insurance regime. The index varies over time since different countries adopted deposit insurance or revised its design features at different points in time.

${ }^{13}$ See Appendix Table 2, available on request.
} 
toward fewer regulatory restrictions. Thus, the timing of the Barth et al. (2001) data actually biases the results against finding a positive relationship between regulatory restrictions on bank activities and the likelihood of suffering a systemic crisis. ${ }^{14}$

We use four measures of bank regulation.

Fraction of Entry Denied is the number of entry applications denied as a fraction of the number of applications received from domestic and foreign entities. This is a measure of entry restrictions in banking and thus the contestability of the market. To the extent restricted entry increases bank profits, this variable would be associated with less fragility. If however, restricted entry induces inefficiencies in the banking market, it could also lead to greater fragility.

Activity Restrictions aggregates measures that indicate whether bank activities in the securities, insurance, and real estate markets and ownership and control of nonfinancial firms are (1) unrestricted, (2) permitted, (3) restricted, or (4) prohibited. The aggregate indicator has therefore a possible maximum variation between four and 16 , with higher numbers indicating more restrictions on bank activities and nonfinancial ownership and control. If these restrictions keep banks from entering excessively risky lines of business, then they may foster banking system stability. If however, restrictions prevent firms from diversifying outside their traditional lines of business, they may increase the fragility of the system.

Required Reserves is the ratio of bank assets that regulators require banks to hold as reserves. Banking systems with higher ratios of required reserves may be more stable since they would have a greater buffer to absorb liquidity shocks. However, greater required reserves are also a tax on the banking system, which may lower profits and raise fragility.

\footnotetext{
${ }^{14}$ Carkovic and Levine (2002) show that the bank regulations in Chile changed very little in the 1990s..
} 
Capital Regulatory Index is a summary measure of capital stringency and is given by the sum of initial capital stringency and overall capital requirements. To the extent that book capital is an accurate measure of bank solvency we expect better capitalized banks to be less fragile.

We also use three additional variables to capture the extent of banking freedom and general economic freedom and the institutional environment.

Banking Freedom is an indicator of the openness of the banking system. It is a composite index of whether foreign banks are able to operate freely, how difficult it is to open domestic banks, how degree of regulation of financial market activities, the presence of state-owned banks, whether the government influences allocation of credit, and whether banks are free to provide customers with insurance products and invest in securities. Higher values indicate fewer restrictions on banking freedoms. On the one hand, fewer official impediments to bank operations and entry could stimulate efficiency and diversification that promotes stability. On the other hand, greater banking freedom could induce destabilizing competition.

Economic Freedom is an indicator of how a country's policies rank in terms of providing economic freedoms. It is a composite of ten indicators ranking policies in the areas of trade, government finances, government interventions, monetary policy, capital flows and foreign investment, banking and finance, wages and prices, property rights, regulation, and black market activity. Higher scores indicate polices more conducive to competition and economic freedom. To the extent freedoms allow banks to improve efficiency and to engage in different activities and diversify their risks, we expect increased level of freedoms to reduce fragility. However, greater freedoms also allow banks to undertake greater risks, particularly if existing regulations distort risk-taking incentives. Thus, overall greater freedom may also lead to greater bank 
fragility. Both Banking and Economic Freedom are available from the Heritage Foundation, are built on expert opinions, and are average values for the period 1995-97.

KKZ_Composite is an index of the overall level of institutional development constructed by Kaufman, Kraay and Zoido-Lobaton (1999). The underlying indicators are voice and accountability, government effectiveness, political stability, regulatory quality, rule of law, and control of corruption. This index is available for 1998. We expect better institutions to lead to reduced bank fragility, controlling for all other factors.

Finally, we control for other national characteristics that the literature has identified as being closely linked to financial sector development. Specifically, we control for whether the country has a British, French German, or Scandinavian Legal Origin because La Porta et al. (1997, 1998), Beck, Demirguc-Kunt, and Levine (2003), and others find that legal origin explains cross-country differences in financial development. We control for legal origin by including dummy variables that take on the value one for the respective legal tradition. We capture the Scandinavian legal origin in the constant. Catholic, Protestant and Muslim are the shares of the respective religion in each country, with the constant capturing other religions. Stulz and Williamson (2003) find that Protestant countries have stronger creditor right protection. We also use the absolute value of a country's Latitude, since Acemoglu, Johnson, and Robinson (2001), Engerman and Sokoloff (1997), Easterly and Levine (2003), and Beck, Demirguc-Kunt, and Levine (2003) show that endowments influence institutional and financial development. Finally, we control for Ethnic Fractionalization, since Easterly and Levine (1997) show that ethnic diversity tends to reduce the provision of public goods, including the institutions that support the contracting environment. 


\section{Methodology}

To test whether bank concentration and competition affect banking system fragility, we follow DD $(1998,2002)$ and use a logit probability model that is robust to heteroskedasticity. ${ }^{15}$ We estimate the probability that a systemic crisis will occur at a particular time in a particular country, assuming that this probability is a function of the explanatory variables $(\mathrm{X}(\mathrm{i}, \mathrm{t}))$. Let $\mathrm{P}(\mathrm{i}$, t) denote a dummy variable that takes the value of one when a banking crisis occurs in country $i$ and time $t$ and a value of zero otherwise. $\beta$ is a vector of $n$ unknown coefficients and $F\left(\beta^{\prime} X(i, t)\right)$ is the cumulative probability distribution function evaluated at $\beta^{\prime} \mathrm{X}(\mathrm{i}, \mathrm{t}){ }^{16}{ }^{16}$ Then, the loglikelihood function of the model is:

$$
\operatorname{Ln} \mathrm{L}=\sum_{\mathrm{t}=1 . . \mathrm{T}} \sum_{\mathrm{i}=1 . . \mathrm{n}}\left\{\mathrm{P}(\mathrm{i}, \mathrm{t}) \ln \left[\mathrm{F}\left(\beta^{\prime} \mathrm{X}(\mathrm{i}, \mathrm{t})\right)\right]+(1-\mathrm{P}(\mathrm{i}, \mathrm{t})) \ln \left[1-\mathrm{F}\left(\beta^{\prime} \mathrm{X}(\mathrm{i}, \mathrm{t})\right)\right]\right\} .
$$

While the sign of the estimated coefficient for each explanatory variable indicates whether an increase of that explanatory variable increases or decreases the probability of a crisis, the estimated coefficients do not indicate the magnitude of the impact of a marginal change in the explanatory variable on the probability of a crisis. Instead, the coefficients reflect the effect of a change in an explanatory variable on $\ln (\mathrm{P}(\mathrm{i}, \mathrm{t}) /(1-\mathrm{P}(\mathrm{i}, \mathrm{t})))$, so that the magnitude of the impact on the probability of a crisis depends on the slope of the cumulative distribution function at $\beta^{\prime} X(i, t)$. Therefore, the magnitude of the change in the probability of a crisis depends on the initial values of all the independent variables and their coefficients. Thus, in the analyses below, we present marginal coefficient estimates that are computed at the sample mean. These

\footnotetext{
${ }^{15}$ Also see Cole and Gunther (1995), Gonzalez-Hermosillo et al. (1997), and Demirguc-Kunt (1989).

${ }^{16}$ Since observations within each country group may also be correlated, we relax the assumption that errors are independent within country observations. We present these robustness tests below.
} 
estimates illustrate the economic magnitudes of the relationship between each explanatory variable and the probability of a systemic banking crisis evaluated at the sample mean.

\section{Results}

\section{A. Main findings}

In Table 2, banking system concentration enters all of the regressions negatively and significantly. Regression (1) presents the results when including the standard explanatory variables; regression (2) adds concentration. ${ }^{17}$ Concentration enters with a significant negative coefficient throughout. In columns (3) and (4), we test the sensitivity of our findings to the treatment of crisis observations after the initial year of the crisis. In column (3), we include all

the crisis period observations. ${ }^{18}$ In column (4), we weight the crisis observations by the length of the crisis. In both cases, our finding of a negative and significant relationship between bank concentration and crisis probability is confirmed. These analyses lend no support to the view that concentration induces banking system instability. Rather, the results suggest that concentrated banking systems are less vulnerable to banking crises.

\footnotetext{
${ }^{17}$ We also ran the column (2) regression without GDP per capita and obtain very similar results on concentration.

${ }^{18}$ When we included subsequent crisis years as non-crisis observations, the results on concentration are similar.
} 
The Table 2 estimates also suggest that the economic impact is large. Regression (2) indicates that a one standard deviation increase in concentration (0.2) leads to a decrease in the probability of a crisis of one percent $(-0.01=0.2 *-0.05)$. Since crisis probabilities at any point in time are quite low (five percent), this is a substantial reduction. When including the subsequent crisis years in the analyses, the estimated effect of a one standard deviation in bank concentration leads to a reduction in the predicted probability of a crisis of 3.5 percent, compared to a sample mean of 18 percent for the sample that includes the years of the crisis. This result is supportive of the concentration-stability view that concentration fosters a more stable banking system.

Among the control variables, GDP growth and per capita GDP enter negatively, while the real interest rates enter positively, as suggested by economic theory and earlier empirical studies. While moral hazard enters positively and significantly in column (1), indicating that deposit insurance design influences banking system stability, it loses significance in some specifications when controlling for bank concentration. A strong negative correlation between concentration and moral hazard might explain the loss of significance of moral hazard. We view the fit of the model as satisfactory given the difficulty in modeling systemic crises. The benchmark specification with concentration classifies 66 percent of all observations and 73 percent of crisis observations accurately (column 2). ${ }^{19}$ Pseudo R-squares range from $6 \%$ to $11 \%$ depending on the specification. The mean predicted probability for crisis observations is $12 \%$, whereas it is $4 \%$ for non-crisis observations. The estimated crisis probability increases prior to the crisis, and the mean for three years prior to crisis is $5 \%$.

To check for a non-linear relationship between concentration and crises, we run a piecewise regression, where concentration is broken into quintiles (Table 2, column 5). We create 
five concentration quintile dummies that equal one if the value of concentration falls within that quintile and zero otherwise. Thus, each observation in the regression has five concentration variables. We multiply the concentration variable by each of the concentration quintile dummy variables, so that four of these equal zero for each observation. The results indicate that the stabilizing effect of concentration is significant for all but the lowest concentration quintile. The coefficient size decreases at higher levels of concentration, but remains negative. The regression (5) results indicate that there is a statistically significant, negative relationship between concentration and banking system fragility for levels of concentration above 35 percent.

\section{B. Sensitivity analyses}

In Table 3, we investigate the sensitivity of the results to using different definitions of a systemic crisis, controlling for reverse causation, employing alternative definitions of banking system concentration, estimating alternative econometric specifications and using alternative samples. In column (1), we change the crisis definition to the one used by Caprio and Klingebiel (1999). ${ }^{20}$ This crisis definition blurs the distinctions between crisis and non-crisis observations, as it includes borderline crises. Nevertheless, we use this alternative definition as a robustness check. The concentration result remains essentially unchanged, negative and significant at ten percent. In column (2) we report results with a different crisis definition where systemic crisis definition excludes the NPL criteria (NPL $>10 \%$ ) and reclassifies these "former" crisis countries as non-crisis countries. This change leaves the results unchanged. In unreported regressions, we

\footnotetext{
${ }^{19}$ In classifying observations, predicted probabilities significantly higher than five percent (number of crisis observations divided by total number of observations which equals the sample mean of the crisis dummy) are classified as crisis observations and those below five percent are classified as no crisis.

${ }^{20}$ Portugal and Guyana are re-defined as non-crisis countries and the following crises are added to the sample: Burundi (1994-97), Canada (1983-85), Congo (1992-97), Denmark (1987-92), and France (1994-95).
} 
also tried excluding these countries from the estimation, which does not affect the significance level of the concentration variable. ${ }^{21}$

Robustness tests indicate that the results are not driven by reverse causality. Reverse causality could arise if systemic crises led to lower levels of concentration in the banking system through greater entry or changes in general competition policies. Although we check the robustness of the results, it is important to reiterate why we use average concentration over the period 1988-1997 for the bulk of the analyses rather than using annual observations. The sample of banks covered by Bankscope changes over the sample period. Thus, measured changes in concentration when using annual data may reflect changes in coverage, not changes in actual concentration. Therefore, using annual data will induce an errors in variables problem that biases the results toward finding an insignificant relationship. Nevertheless, we undertake the following sensitivity analyses. First, we inspect individual crisis cases in our sample. We do not see a significant pattern of reduced concentration after crisis episodes, and indeed the data suggest that concentration generally varies little over time. Second, we estimate a specification using the initial level of concentration (1988 or the first available year in the data) instead of the 1988-97 average. Table 3 regression (3) shows that this does not change our results significantly: concentration is negatively associated with the likelihood of suffering a crisis. ${ }^{22}$

As additional robustness checks, we use the Herfindahl index of concentration, which is the sum of the squared market shares. Given that our sample size changes over the sample period, including banks beyond the top three might introduce measurement bias. For this

\footnotetext{
${ }^{21}$ In unreported regressions, we also excluded from the systemic crisis definition NPL as well crisis cost criteria (crisis costs $>2 \%$ of GDP) and re-classified all these observations as non-crisis observations; the coefficient on concentration is still negative and significant at the six percent level.

${ }^{22}$ Since some of the crisis episodes occur before the date beginning date of data on concentration, we re-ran the regression without those crisis episodes that precede the initial concentration date. This leaves us with only 20 crisis episodes and less than half of the total number of observations, yet the concentration variable still remains negative and significant. We also confirm our results using annual data.
} 
reasons, we favor the three-bank concentration indicator, which equals the share of assets of the three largest banks relative to total banking system assets. Nevertheless, the result using the Herfindahl index for all available banks indicates a negative and significant (at the ten percent level) relationship between concentration and crises (column 4). ${ }^{23}$

Thus far, we have allowed for heteroskedasticity of errors and corrected for it, but assumed that the errors are independent. Given that we use a panel data set, the error terms within individual countries may be correlated with each other. To control for the fact that omitted country-level characteristics might cause correlation of the error terms within countries, Table 3, column (5) reports results that allow for clustering within countries. Specifically, we require that error terms are independent across countries but not necessarily within countries. Concentration still enters with a negative and significant coefficient. ${ }^{24}$

We also investigate the sensitivity of our results to using alternative samples. In column (6) of Table 3, we exclude all countries with populations of less than 20 million. $^{25}$ In column (7), we exclude G-10 countries. In both cases, we continue to find a negative relationship between crises and concentration. ${ }^{26}$ Running the regression with only G-10 or high-income countries yields a negative but insignificant relationship between concentration and crisis. The drop in significance can be explained by (i) the low number of crises in developed countries over the sample period, and (ii) the fact that the rich country sample is much smaller.

\footnotetext{
${ }^{23}$ We also use a survey-based measure of concentration from the Barth et al. (2004) database, which defines bank concentration as the share of deposits of the largest five banks. The correlation between the concentration measures calculated from Bankscope data and from Barth et al. is 52\%, significant at the $1 \%$-level. Using this measure reduces our sample greatly, but still yields a negative coefficient, significant at the $13 \%$ level.

${ }^{24} \mathrm{We}$ also estimated a logit model with random country effects. Again, the results are not significantly different and we cannot reject the Hausman null hypothesis that the differences in coefficients estimated using random country errors and those using fixed effects estimations are not systematic.

${ }^{25}$ Eliminating countries with less than 1 million or less than 10 million inhabitants yielded similar results. Excluding African countries, which tend to have very high bank concentration ratios, does not change our results either.
} 
Finally, we control for Bank Size, which equals total banking system assets divided by the number of banks in billions of US\$. If concentration is simply proxying for the average size of banks in a country, then including Bank Size will drive out the significance of concentration. Regression (8), however, indicates that concentration continues to enter negatively and significantly when controlling for Bank Size, but Bank Size does not enter significantly.

C. Concentration, regulations, institutions, and crises

In Table 4, we control for different bank regulations and the institutional environment. ${ }^{27}$ We include indicators of bank regulations for three reasons. First, controlling for differences in national policies provides a simple robustness test of the relationship between concentration and crises. Second, controlling for regulations provides additional information on the concentrationfragility relationship. If concentration is proxying for regulations that impede competition, then controlling for the regulatory environment will drive out the significance of concentration in the crisis regression and therefore explain why we find a significant, negative coefficient on concentration. Finally, examining the relationship between bank regulations and banking system stability is independently valuable. Countries implement regulations to promote banking system stability. This research provides some information about which policies work. ${ }^{28}$

The Table 4 results indicate that the negative relationship between banking system concentration and the probability of suffering a systemic banking crisis holds even when

\footnotetext{
${ }^{26} \mathrm{We}$ also tested the sensitivity of our findings to outliers. Specifically, we excluded Cote d'Ivoire (1993) because their M2/reserves values are outliers and Peru (1991) because its inflation and real interest rate values are outliers. Our findings are confirmed. Further, when we lag all observations by one period, our results are again confirmed. ${ }^{27} \mathrm{We}$ also controlled for public and foreign ownership. While we cannot find a robust relationship between the ownership structure and banking system stability, controlling for the ownership structure does not affect our main finding of a negative relationship between concentration and crisis probability.

${ }^{28}$ These specifications exclude GDP per capita since it is also a proxy for the overall institutional environment, including bank regulations. We have also estimated specifications where we have left out the concentration variable and included only the regulation. The results are virtually unchanged.
} 
including measures of the regulatory environment, the general openness of the banking industry, the degree of economic freedom in the economy, and a general index of institutional development. ${ }^{29}$ When controlling for capital regulations, reserve requirements, banking freedom, economic freedom and a summary measure of institutional development, concentration enters negative and significantly at the five percent level. When controlling for the fraction of entry applications denied and regulatory restrictions on the activities of banks, concentration enters negatively and significantly at the ten percent level. ${ }^{30}$

The Table 4 results also indicate that tighter entry restrictions and more severe regulatory restrictions on bank activities boost bank fragility. These are consistent with the results obtained by Barth et al. (2004), who examine the impact of entry restrictions on crises in a purely crosscountry investigation that does not control for bank concentration. A higher fraction of entry applications denied - a proxy for tighter entry regulations - leads to higher levels of fragility in the banking system. This is consistent with the argument that restricted entry reduces the efficiency of the banking system, also making it more vulnerable to external shocks. Similarly, we find that restrictions on bank activities increase crisis probabilities. This result indicates that overall these restrictions prevent banks from diversifying outside their traditional business, reducing their ability to reduce the riskiness of their portfolios. The required reserves and capital regulatory index do not enter with significant coefficients. ${ }^{31}$

\footnotetext{
${ }^{29}$ Bank concentration remains significantly, negatively associated with bank fragility even when simultaneously controlling for the regulatory variables and the institutional development indicators, but the intersection of these regulatory and institutional variables cuts the number of observations virtually in half.

${ }^{30}$ In unreported regressions we have also explored specifications where we have interacted the concentration variable with these regulatory and institutional variables, but the interaction terms did not enter significantly.

${ }^{31}$ Including all the regulatory variables simultaneously (i) does not change the results on concentration and (ii) does not yield significant coefficients on the regulatory variables because they are highly correlated with each other. The only specification in which the relationship between concentration and systemic crisis probability turns insignificant is the one where all explanatory variables are included at the same time and where endogeneity problems are circumvented by focusing on initial crisis years and by lagging the explanatory variables. We conjecture that this
} 
The variables that capture the general openness and competitiveness of the banking system and the economy enter with negative and very significant coefficients (Table 4 regressions 5-7). Thus countries with greater freedoms in banking and generally more competitive economic policies are less likely to experience banking crises. This is the case despite the fact that these policies also tend to reduce entry barriers and are correlated with reduced levels of bank concentration. A better institutional environment is also associated with a lower probability of systemic crisis, as expected. In regression (8), we include two of the institutional indicators simultaneously. As shown, there is multicollinearity across the different institutional variables (though they jointly enter significantly). Even when simultaneously including these controls, however, concentration enters negatively and significantly. The evidence is consistent with theories that emphasize the stabilizing effects of competition, but inconsistent with the many models that stress the destabilizing effects from competition.

In Table 5, we explore the linkages between systemic banking crises and concentration while controlling for other national characteristics that may explain institutional development, such as legal origin, religious composition, geography, and ethnic diversity. The negative relationship between banking system concentration and systemic crises remains negative and significant even when controlling for these other factors.

The findings that (i) concentration lowers banking system fragility and (ii) low competition raises banking system fragility imply that future research needs to move beyond a simple "concentration-stability" versus "concentration-fragility" debate where concentration is viewed as a simple proxy for market power. More specifically, one standard view holds that concentrated banking systems reduce banking system fragility by boosting the profits of banks.

outlier result can be explained by the substantially lower number of observations and by multicollinearity among the many explanatory variables. 
Recall, however, that this paper finds that (i) concentration remains negatively associated with banking system fragility when controlling for regulations and institutions associated with competition and (ii) these indicators of competition are associated with greater banking system stability. If our regulatory and institutional indicators do a reasonably good job of measuring the competitiveness of the banking industry, then these results (i) are inconsistent with the argument that concentration enhances stability by boosting the market power of banks and (ii) indicate that concentration is measuring "something else" besides market power. We hope that future studies at the individual bank-level can identify why bank concentration is negatively correlated with bank fragility even after controlling for the degree of competition in the banking industry.

\section{Conclusions}

This paper investigates the impact of bank concentration and bank concentration on banking system fragility. We use cross-country data on 69 countries and 47 crisis episodes. The paper conducts an array of sensitivity analyses that extend the core results.

The results are consistent with concentration-stability theories but are inconsistent with the concentration-fragility views. These initial analyses indicate that national bank concentration tends to reduce the likelihood that a country will suffer a systemic banking crisis. The results hold when controlling for a wide array of macroeconomic, regulatory and institutional factors, when using different definitions of crises and concentration, and after examining different subsamples of countries.

In terms of regulations and institutions, the data do not support the view that more competition increases fragility. Quite to the contrary, the results indicate that banking systems where a larger fraction of entry applications are denied, and those where regulations restrict 
banks from engaging in non-loan making activities have a greater likelihood of experiencing a systemic crisis. Similarly, in terms of national institutions, the regressions indicate that countries with better-developed institutions that foster competition are less likely to suffer systemic banking crises. The finding that both concentration and competitiveness of the banking system is positively related to banking stability suggests that bank concentration is an insufficient measure of bank competitiveness.

While our paper shows that more concentrated banking systems are less likely to suffer systemic crises, we do not explore the mechanisms. While policy-relevant, our findings should therefore not be seen as a recommendation for policymakers to foster bank concentration. Future research has to examine the channels through which concentration and the competitiveness of the financial system impact stability. 


\section{References}

Allen, Franklin, 1990. "The Market for Information and the Origin of Financial Intermediation." Journal of Financial Intermediation 1, 3-30.

Allen, Franklin and Douglas Gale, 2000. Comparing Financial Systems. Cambridge, MA: MIT Press.

Allen, Franklin and Douglas Gale, 2004. "Competition and Financial Stability." Journal of Money, Credit, and Banking 36 (3 Pt.2), 433-480.

Bank for International Settlement, 2001. "The Banking Industry in the Emerging Market Economies: Competition, Consolidation, and Systemic Stability", BIS Paper 4.

Barth, James R., Caprio Jr., Gerard and Levine, Ross, 2001, "Banking Systems Around the Globe: Do Regulation and Ownership Affect Performance and Stability?" In: F. Mishkin (ed.), Financial Supervision and Regulation: What Works and What Doesn't, Chicago, IL: Chicago University Press, 31-88.

Barth, James R., Caprio Jr., Gerard and Levine, Ross, 2004, "Bank Supervision and Regulation: What Works Best?" Journal of Financial Intermediation 13(2), 205-48.

Barth, James R., Caprio Jr., Gerard and Levine, Ross, 2005, Rethinking Bank Regulation: Until Angels Govern. Cambridge University Press, forthcoming.

Beck, Thorsten, Demirgüç-Kunt, Asli, and Levine, Ross, 2000, "A New Database on the Structure and Development of the Financial Sector" The World Bank Economic Review $\underline{14}, 597-605$.

Beck, Thorsten, Demirgüç-Kunt, Asli, and Levine, Ross, 2003. "Law, Endowments, and Finance". Journal of Financial Economics 70, 137-181.

Besanko, David and Thakor, Anjan V., 1993. "Relationship Banking, Deposit Insurance and Bank Portfolio", in: Mayer, C. and Vives, X. (eds.): Capital Markets and Financial Intermediation, Cambridge, UK: Cambridge University Press, 292-318.

Boot, Arnoud W. and Greenbaum, Stuart, 1993. "Bank Regulation, Reputation, and Rents: Theory and Policy Implications", ", in: Mayer, Colin and Vives, Xavier (eds.): Capital Markets and Financial Intermediation, Cambridge, UK: Cambridge University Press, 292-318.

Boyd, John H., and De Nicolo, Gianni, 2005. "The Theory of Bank Risk-Taking and Competition Revisited" Journal of Finance, forthcoming. 
Boyd, John H. and Graham, Stanley, 1991. Investigating the Banking Consolidation Trend, Federal Reserve Bank of Minneapolis Quarterly Review, Spring, 1-15.

Boyd, John H. and Graham, Stanley, 1998. "Consolidation in US Banking," in Y. Amihud and G. Miller (eds.), Bank Mergers and Acquisitions, Norwell, MA. Kluwer, pp. 113-135.

Boyd John H. and Runkle, David E., 1993. "Size and Performance of Banking Firms: Testing the Predictions of Theory." Journal of Monetary Economics 31, 47-67.

Boyd John H., and Prescott, Edward C., 1986. "Financial Intermediary-Coalitions." Journal of Economic Theory 38, 211-232.

Calomiris, Charles W., 2000. U.S. Bank Deregulation in Historical Perspective. Cambridge University Press.

Calomiris, Charles W. and. Mason, Joseph R., 2000. "Causes of Bank Distress During the Great Depression”, National Bureau of Economic Research, Working Paper No. 7919, Cambridge, MA.

Caminal, Ramon and Matutes, Carmen, 2002. "Market Power and Banking Failures", International Journal of Industrial Organization 20, 1341-61.

Caprio, Gerard, Jr. and Klingebiel, Daniela, 1999, "Episodes of Systematic and Borderline Financial Distress", mimeo, The World Bank.

Carkovic, Maria and Levine, Ross, 2002. "Finance and Growth: New Evidence and Policy Analyses for Chile," In Norman Loayza and Raimundo Soto, Editors, Economic Growth: Sources, Trends, and Cycles, Santiago, Chile: Central Bank of Chile, pp. 343-376.

Carletti, Elena and Hartmann, Philipp, 2003. "Competition and Stability: What's Special about Banking?”, in Mizen, Paul (ed.): Monetary History, Exchange Rates and Financial Markets: Essays in Honor of Charles Goodhart, Edward Elgar.

Chan, Yuk-Shee, Greenbaum, Stuart and Thakor, Anjan, 1992. "Is Fairly Priced Deposit Insurance Possible?" Journal of Finance 47, 227-245.

Chong, Beng Soon, 1991. 'Effects of Interstate Banking on Commercial Banks' Risk and Profitability", Review of Economics and Statistics 73, 78-84.

Claessens, Stijn, Demirguc-Kunt, Asli and Huizinga, Harry, 2001. "How Does Foreign Entry Affect Domestic Banking Markets?” Journal of Banking and Finance 25(5), 891-911.

Claessens, Stijn and Laeven, Luc, 2004.'What Drives Bank Competition? Some International Evidence." Journal of Money, Credit, and Banking 36 (3 Pt.2), 563-583. 
Cole, Rebel A. and Gunther, Jeffery W., 1993. "Separating the Likelihood and Timing of Bank Failure." Journal of Banking and Finance 19(6), 1073-89.

Cordella, Tito and Yeyati, Eduardo Levy, 2002. "Financial Opening, Deposit Insurance, and Risk in a Model of Banking Competition", European Economic Review 46, 471-485.

Demirgüç-Kunt, Asli, 1989. "Deposit-Institution Failures: A Review of Empirical Literature," Economic Review, Federal Reserve Bank of Cleveland, Vol. 25, No.4.

Demirgüç-Kunt, Asli, and Detragiache, Enrica, 1998, "The Determinants of Banking Crises in Developing and Developed Countries”, IMF Staff Papers 45 (1), pp. 81-109.

Demirgüç-Kunt, Asli, and Detragiache, Enrica, 1999, "Financial Liberalization and Financial Fragility”, in B. Pleskovic and J.E. Stiglitz (Eds.) Proceedings of the 1998 World Bank Conference on Development Economics, Washington, DC, The World Bank.

Demirgüç-Kunt, Asli, and Detragiache, Enrica, 2002, "Does Deposit Insurance Increase Banking System Stability? An Empirical Investigation." Journal of Monetary Economics, 49 (7), pp.1373-1406.

Demirgüç-Kunt, Asli, Laeven, Luc and Levine, Ross, 2004, "Regulations, Market Structure, Institutions, and the Cost of Financial Intermediation." Journal of Money, Credit and Banking 36 (3 Pt.2), 593-622.

De Nicoló, Gianni, 2000. "Size, Charter Value and Risk in Banking: An International Perspective." International Finance Discussion Paper \#689, Board of Governors of the Federal Reserve System.

De Nicoló, Gianni, Batholomew, Philip, Zaman, Jahanara, and Zephirin, Mary, 2003. "Bank Consolidation, Conglomeration and Internationalization: Trends and Implications for Financial Risk.” IMF Working Paper \#03/158.

Diamond, Douglas W., 1984. "Financial Intermediation and Delegated Monitoring." Review of Economic Studies 51, 393-414.

Dick, Astrid, 2003. "Nationwide Branching and Its Impact on Market Structure, Quality and Bank Performance.” Journal of Business, forthcoming.

Easterly, William and Levine, Ross, 1997, "Africa's growth tragedy: policies and ethnic divisions." Quarterly Journal of Economics 112, 1203-1250.

Easterly, William and Levine, Ross 2003. "Tropics, Germs, and Crops: How Endowments Influence Economic Development," Journal of Monetary Economics 50, 3-39.

Flannery, Mark J., 1989. "Capital Regulation and Insured Banks' Choice of Individual Loan Default Risks.” Journal of Monetary Economics 24, 235-258. 
Gonzalez-Hermosillo, Brenda, Pazarbasioglu, Ceyla,, and Billings, Robert, 1997. "Banking System Fragility: Likelihood Versus Timing of Failure - An Application to the Mexican Financial Crisis," IMF Staff Papers.

Group of Ten, 2001. Report on Consolidation in the Financial Sector, Bank for International Settlements: Basel, Switzerland.

Hellman, Thomas, Murdock, Kevin and. Stiglitz, Joseph E, 2000. "Liberalization, Moral Hazard in Banking and Prudential Regulation: Are Capital Controls enough?" American Economic Review 90(1), 147-165.

Hughes, Joseph P. and Mester, Loretta, 1998. "Bank Capitalization and Cost: Evidence of Scale Economies in Risk Management and Signaling", Review of Economics and Statistics 80, $314-25$.

International Monetary Fund, 2001. Financial Sector Consolidation in Emerging Markets, Chapter V, International Capital Market Report.

Jayaratne, Jith and Strahan, Philip, 1998."Entry Restrictions, Industry Evolution, and Dynamic Efficiency: Evidence From Commercial Banking." Journal of Law and Economics 41 $239-75$.

Kaminsky, Graciela, and Reinhart, Carmen, 1999. "The Twin Crises: The Causes of Banking and Balance of Payments Problems.” American Economic Review 89, 473-500.

Kane, Edward J., 1989. The S\&L Insurance Mess: How Did It Happen? Washington: Urban Institute Press.

Kaufman, Daniel, Kraay, Aart, and Zoido-Lobaton, Pablo. 1999. "Governance Matters.” World Bank Policy Research Department Working Paper No. 2196.

Keeley, Michael C., 1990. "Deposit Insurance, Risk and Market Power in Banking", American Economic Review 80, 1183-1200.

La Porta, Rafael, Lopez-de-Silanes, Florencio, Shleifer, Andrei, and Vishny, Robert W., 1997. "Legal determinants of external finance." Journal of Finance 52, 1131-1150.

La Porta, Rafael, Lopez-de-Silanes, Florencio, Shleifer, Andrei, and Vishny, Robert W., 1999. "The Quality of Government." Journal of Law, Economics, and Organization 15, 222279.

Lindgren, Carl-Johan, Gillian Garcia, and Matthew I. Saal, 1996, Bank Soundness and Macroeconomic Policy, (Washington: International Monetary Fund). 
Macey, Jonathan R., O'Hara, Maureen, 2003, “The corporate governance of banks,” FRBNY Economic Policy Review 9, 91-107.

Matutes, Carmen and Vives, Xavier, 1996. "Competition for Deposits, Fragility and Insurance", Journal of Financial Intermediation 5, 184-216.

Matutes, Carmen and Vives, Xavier, 2000. "Imperfect Competition, Risk Taking and Regulation in Banking", European Economic Review 44, 184-216.

Merton, Robert C., 1977." An Analytic Derivation of the Cost of Deposit Insurance and Loan Guarantees: An Application of Modern Option Pricing Theory.” Journal of Banking and Finance 1, 3-11.

Mishkin, Frederic S., 1999. “Financial Consolidation: Dangers and Opportunities.” Journal of Banking and Finance 23, 675-691.

O'Hara, Maureen and Shaw, Wayne, 1990. "Deposit Insurance and Wealth Effects: The Value of Being 'Too Big to Fail', ’ Journal of Finance 45, 1587- 1600.

Ramakrishnan, Ram and Thakor, Anjan V., 1984. "Information Reliability and A Theory of Financial Intermediation.” Review of Economic Studies 51, 415-432.

Sharpe, William F., 1978. "Bank Capital Adequacy, Deposit Insurance and Security Values." Journal of Financial and Quantitative Analysis 13, 701-718.

Smith, Bruce D., 1984. "Private Information, Deposit Interest Rates, and the 'Stability' of the Banking System", Journal of Monetary Economics 14, 293-317.

Stiglitz, Joseph E., 1972. "Some Aspects of the Pure Theory of Corporate Finance: Bankruptcies and Takeovers." Bell Journal of Economics 3, 458-82.

Stulz, Rene and Williamson, Rohan, 2003. "Culture, Openness, and Finance.” Journal of Financial Economics 70, 313-49.

Williamson, Stephen D., 1986. " Costly Monitoring, Financial Intermediation, and Equilibrium Credit Rationing.” Journal of Monetary Economics 18, 159-179. 


\section{Table 1. Summary Statistics}

Banking crisis is a crisis dummy, which takes on the value of one if there is a systemic and the value of zero otherwise. Growth is the rate of growth of real GDP. Terms of trade equals the change in the terms of trade of goods and services. Real interest rate is the nominal interest rate minus the contemporaneous rate of inflation. Inflation is the rate of change of the GDP deflator. $\mathrm{M} 2 /$ reserves is the ratio of M2 to international reserves. Credit growth is the real growth of domestic credit, lagged two periods. Depreciation is the rate of change of the exchange rate. Moral hazard is an aggregate index of moral hazard associated with varying deposit insurance schemes. Concentration is calculated as the fraction of assets held by the three largest banks in each country, averaged over the sample period. Fraction of entry applications denied is the number of entry applications denied as a fraction of the number of applications received from domestic and foreign entities. Activity restrictions measures the degree to which a bank is restricted from engaging in business of securities underwriting, insurance underwriting and selling, and from real estate investment, management, and development. Required reserves is the percentage of reserves regulators require banks to hold. Capital regulatory index measures capital stringency in the banking system. Banking freedom is an indicator of the relative openness of the banking system. Economic freedom is a composite measure of institutional factors determining economic freedom. KKZ_composite is a composite measure of governance indicators. Legal origin includes the three dummies UK, France and Germany, which take the value 1 for each legal origin respectively. Latitude is the absolute value of the latitude of each country normalized to lie between zero and one. Religion includes three variables, Catholic, Muslim, Protestant, which indicate the percentage of the population that follows a particular religion. Ethnic Fractionalization is the probability that two randomly selected individuals in a country will not speak the same language. Detailed variable definitions and sources are given in the data appendix, available on request.

\begin{tabular}{lccccc}
\hline Variable & Obs. & Mean & St. Dev. & Maximum & Minimum \\
\hline Banking crisis & 1138 & 0.05 & 0.21 & 0 & 1 \\
Growth & 1138 & 3.30 & 4.24 & -16.40 & 23.60 \\
Terms of trade change & 1138 & 0.17 & 10.03 & -51.45 & 63.24 \\
Real interest rate & 1138 & -5.39 & 185.00 & -5845.19 & 192.90 \\
Inflation & 1138 & 23.37 & 203.18 & -29.17 & 6134.79 \\
M2/reserves & 1138 & 23.51 & 81.30 & 0.19 & 1372.94 \\
Depreciation & 1138 & 0.11 & 0.27 & -0.35 & 4.26 \\
Credit Growth ${ }_{\text {t-2 }}$ & 1138 & 6.12 & 15.66 & -54.62 & 115.42 \\
Real GDP per capita & 1138 & 8282.29 & 10638.37 & 148.18 & 45950.46 \\
Moral hazard & 1138 & -0.87 & 2.36 & -2.49 & 3.98 \\
Concentration & 69 & 0.71 & 0.22 & 0.19 & 1 \\
Fraction of entry applications & & & & & \\
denied & 41 & 0.20 & 0.28 & 0 & 1 \\
Activity restrictions & 53 & 9.38 & 2.55 & 4 & 14 \\
Required reserves & 41 & 11.81 & 11.67 & 0 & 43 \\
Capital regulatory index & 52 & 5.52 & 1.69 & 2 & 8 \\
Banking freedom & 67 & 3.37 & 0.85 & 2 & 5 \\
Economic freedom & 67 & 3.21 & 0.61 & 1.9 & 4.5 \\
KKZ_composite & 69 & 0.32 & 0.81 & -1.03 & 1.72 \\
British Legal Origin & 69 & 0.39 & 0.49 & 0 & 1 \\
French Legal Origin & 69 & 0.48 & 0.50 & 0 & 1 \\
German Legal Origin & 69 & 0.07 & 0.26 & 0 & 1 \\
Latitude & 69 & 0.29 & 0.20 & 0.01 & 0.71 \\
Catholic & 69 & 36.08 & 36.88 & 0 & 96.60 \\
Muslim & 69 & 15.00 & 28.27 & 0 & 99.40 \\
Protestant & 69 & 16.36 & 24.00 & $-1.53 \mathrm{E}-06$ & 97.80 \\
Ethnic Fractionalization & 68 & 0.32 & 0.30 & 0 & 0.86 \\
\hline
\end{tabular}




\section{Table 2. Banking Crisis and Concentration}

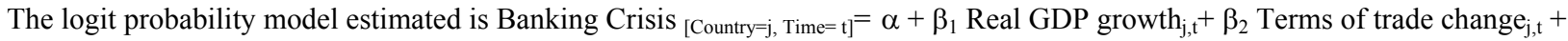
$\beta_{3}$ Real interest rate $\mathrm{j}_{\mathrm{j}, \mathrm{t}}+\beta_{4}$ Inflation $_{\mathrm{j}, \mathrm{t}}+\beta_{5} \mathrm{M} 2$ reserves $_{\mathrm{j}, \mathrm{t}}+\beta_{6}$ Depreciation $_{\mathrm{j}, \mathrm{t}}+\beta_{7}$ Credit growth $_{\mathrm{j}, \mathrm{t}-2}+\beta_{8}$ Real GDP per capita $_{\mathrm{j}, \mathrm{t}}+\beta_{9}$ Moral Hazard Index $\mathrm{j}_{\mathrm{j}, \mathrm{t}}+\beta_{10}$ Concentration $_{\mathrm{j}, \mathrm{t}}+\varepsilon_{\mathrm{j}, \mathrm{t}}$. The dependent variable is a crisis dummy that takes on the value of one if there is a systemic and the value of zero otherwise. Growth is the rate of growth of real GDP. Terms of trade equals the changes in the terms of trade of goods and services. Real interest rate is the nominal interest rate minus the contemporaneous rate of inflation. Inflation is the rate of change of the GDP deflator. M2/reserves is the ratio of M2 to international reserves. Credit growth is the real growth of domestic credit, lagged two periods. Depreciation is the rate of change of the exchange rate. Moral hazard is an aggregate index of moral hazard associated with varying deposit insurance schemes. Concentration is calculated as the fraction of assets held by the three largest banks in each country, averaged over the sample period. Bank data are from the Bankscope database of Fitch IBCA. Specifications (1) and (2) exclude crisis observations after the initial crisis year. Specification (3) includes the crisis period as crisis observations. Specification (4) weights crisis years by duration of crisis. In specification (5), we run piece-wise regressions where concentration is split into quintiles and entered 5 times, each time multiplied by a dummy that takes the value 1 for each quintile. We present the marginal effects (dy/dx) of the logit regressions. White's heteroskedasticity consistent standard errors are given in parentheses. Detailed variable definitions and sources are given in the data appendix, available on request.

\begin{tabular}{|c|c|c|c|c|c|}
\hline & (1) & (2) & (3) & (4) & (5) \\
\hline Real GDP growth & $\begin{array}{c}-0.0052 * * * \\
(0.0011)\end{array}$ & $\begin{array}{c}-0.0053 * * * \\
(0.0011)\end{array}$ & $\begin{array}{c}-0.0121 * * * \\
(0.0026)\end{array}$ & $\begin{array}{c}-0.0201 * * * \\
(0.0025)\end{array}$ & $\begin{array}{c}-0.0048 * * * \\
(0.0010)\end{array}$ \\
\hline Terms of trade change & $\begin{array}{l}-0.0005 \\
(0.0004)\end{array}$ & $\begin{array}{l}-0.0004 \\
(0.0004)\end{array}$ & $\begin{array}{l}-0.0011 \\
(0.0010)\end{array}$ & $\begin{array}{c}-0.0027 * * * \\
(0.0010)\end{array}$ & $\begin{array}{l}-0.0003 \\
(0.0003)\end{array}$ \\
\hline Real interest rate & $\begin{array}{c}0.0003 * * \\
(0.0001)\end{array}$ & $\begin{array}{c}0.0003 * * \\
(0.0001)\end{array}$ & $\begin{array}{c}0.0007 * * \\
(0.0003)\end{array}$ & $\begin{array}{c}0.0013 * * * \\
(0.0005)\end{array}$ & $\begin{array}{c}0.0005^{* * *} \\
(0.0001)\end{array}$ \\
\hline Inflation & $\begin{array}{c}0.0003 \\
(0.0003)\end{array}$ & $\begin{array}{c}0.0003 \\
(0.0003)\end{array}$ & $\begin{array}{c}0.0007 * * \\
(0.0003)\end{array}$ & $\begin{array}{c}0.0022 * * * \\
(0.0007)\end{array}$ & $\begin{array}{c}0.0003 \\
(0.0003)\end{array}$ \\
\hline M2/reserves & $\begin{array}{c}0.0000 \\
(0.0000)\end{array}$ & $\begin{array}{c}0.0001 \\
(0.0000)\end{array}$ & $\begin{array}{l}0.0003 * * \\
(0.0001)\end{array}$ & $\begin{array}{c}0.0003 * * \\
(0.0001)\end{array}$ & $\begin{array}{c}0.0000 \\
(0.0000)\end{array}$ \\
\hline Depreciation & $\begin{array}{c}0.0191 \\
(0.0368)\end{array}$ & $\begin{array}{c}0.0138 \\
(0.0362)\end{array}$ & $\begin{array}{c}0.0832 \\
(0.0570)\end{array}$ & $\begin{array}{l}-0.1537 * \\
(0.0810)\end{array}$ & $\begin{array}{c}0.0200 \\
(0.0320)\end{array}$ \\
\hline Credit Growth $_{\mathrm{t}-2}$ & $\begin{array}{c}0.0004 \\
(0.0003)\end{array}$ & $\begin{array}{c}0.0004 \\
(0.0003)\end{array}$ & $\begin{array}{c}0.0001 \\
(0.0007)\end{array}$ & $\begin{array}{c}0.0024 * * * \\
(0.0006)\end{array}$ & $\begin{array}{c}0.0004 \\
(0.0003)\end{array}$ \\
\hline Real GDP per capita & $\begin{array}{c}-1.39 \mathrm{e}-06^{* *} \\
(0.0000)\end{array}$ & $\begin{array}{c}-1.45 \mathrm{e}-06^{* *} \\
(0.0000)\end{array}$ & $\begin{array}{c}-4.87 \mathrm{e}-06^{* * *} \\
(0.0000)\end{array}$ & $\begin{array}{c}-4.85 \mathrm{e}-06^{* * * *} \\
(0.0000)\end{array}$ & $\begin{array}{c}-1.60 \mathrm{e}-06^{* *} \\
(0.0000)\end{array}$ \\
\hline Moral Hazard Index & $\begin{array}{l}0.0050 * * \\
(-0.0022)\end{array}$ & $\begin{array}{c}0.0032 \\
(0.0023)\end{array}$ & $\begin{array}{c}0.0166^{* * * *} \\
(0.0048)\end{array}$ & $\begin{array}{c}0.0156 * * * \\
(0.0047)\end{array}$ & $\begin{array}{l}0.0040^{*} \\
(0.0022)\end{array}$ \\
\hline Concentration & & $\begin{array}{c}-0.0517 * * \\
(0.0251)\end{array}$ & $\begin{array}{c}-0.1591 * * * \\
(0.0562)\end{array}$ & $\begin{array}{c}-0.1527 * * * \\
(0.0500)\end{array}$ & \\
\hline Concentration*Quint1 & & & & & $\begin{array}{l}-0.2432 \\
(0.1541)\end{array}$ \\
\hline Concentration*Quint2 & & & & & $\begin{array}{c}-0.2427 * * \\
(0.0983)\end{array}$ \\
\hline Concentration*Quint3 & & & & & $\begin{array}{c}-0.1929 * * * \\
(0.0674)\end{array}$ \\
\hline Concentration*Quint4 & & & & & $\begin{array}{c}-0.1776 * * * \\
(0.0551)\end{array}$ \\
\hline Concentration*Quint5 & & & & & $\begin{array}{c}-0.1170 * * * \\
(0.0447)\end{array}$ \\
\hline No. of Crises & 47 & 47 & 196 & 200 & 47 \\
\hline No. of Observations & 989 & 989 & 1138 & 1142 & 989 \\
\hline$\%$ crises correct & 61 & 66 & 61 & 65 & 66 \\
\hline$\%$ correct & 73 & 73 & 65 & 69 & 73 \\
\hline Pseudo $\mathrm{R}^{2}$ & 0.0942 & 0.1135 & 0.0856 & 0.0622 & 0.1474 \\
\hline
\end{tabular}

$* * * * *$, and $*$ indicate statistical significance at 1,5 , and 10 percent, respectively. 


\section{Table 3. Banking Crisis and Concentration: Alternative Crisis and Concentration Measures}

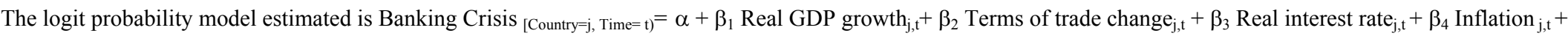
$\beta_{5} \mathrm{M} 2 /$ reserves $_{\mathrm{j}, \mathrm{t}}+\beta_{6}$ Depreciation $_{\mathrm{j}, \mathrm{t}}+\beta_{7}$ Credit growth $_{\mathrm{j}, \mathrm{t}-2}+\beta_{8}$ Real GDP per capita $_{\mathrm{j}, \mathrm{t}}+\beta_{9}$ Moral Hazard Index $_{\mathrm{j}, \mathrm{t}}+\beta_{10}$ Concentration $_{\mathrm{j}, \mathrm{t}}+\varepsilon_{\mathrm{j}, \mathrm{t}}$. The dependent variable is a crisis dummy that takes on the value of one if there is a systemic and the value of zero otherwise. Growth is the rate of growth of real GDP. Terms of trade equals the change in the terms of trade of goods and services. Real interest rate is the nominal interest rate minus the contemporaneous rate of inflation. Inflation is the rate of change of the GDP deflator. $\mathrm{M} 2 /$ reserves is the ratio of M2 to international reserves. Credit growth is the real growth of domestic credit, lagged two periods. Depreciation is the rate of change of the exchange rate. Moral hazard is an aggregate index of moral hazard associated with varying deposit insurance schemes. The aforementioned variables are used in analysis but not shown for the sake of brevity. Concentration is calculated as the fraction of assets held by the three largest banks in each country, averaged over the sample period. Bank data are from the Bankscope database of Fitch IBCA. Specification (1) uses an alternative definition of crisis, based on Caprio and Klingebiel (1999). In specification (2), we reclassify those countries whose only criteria for crisis classification is non-performing loans $>10 \%$. In specification (3), Average Concentration is replaced by Initial Concentration, for the entire sample period. In specification (4) the concentration measure used is the Herfindahl index. Specification (5) relaxes the assumption of independent error terms within countries (clustering). In specification (6) the sample excludes all countries with populations less than 20 million. In specification (7) the sample excludes G-10 countries. In specification (8), we control for mean bank size, which is given in billions of US\$. White's heteroskedasticity consistent standard errors are given in parentheses. Detailed variable definitions and sources are given in the data appendix, available on request.

\begin{tabular}{|c|c|c|c|c|c|c|c|c|}
\hline & (1) & (2) & (3) & (4) & $(5)$ & (6) & (7) & $(8)$ \\
\hline Concentration & $\begin{array}{c}-0.0448^{*} \\
(0.0261)\end{array}$ & $\begin{array}{c}-0.0488^{* *} \\
(0.0228)\end{array}$ & $\begin{array}{l}-0.0531^{*} \\
(0.0256)\end{array}$ & $\begin{array}{l}-0.0536^{*} \\
(0.0325)\end{array}$ & $\begin{array}{c}-0.0517 * * \\
(0.0236)\end{array}$ & $\begin{array}{c}-0.2182 * * * \\
(0.0737)\end{array}$ & $\begin{array}{c}-0.0494 * \\
(0.0280)\end{array}$ & $\begin{array}{c}-0.0465^{*} \\
(0.0246)\end{array}$ \\
\hline No. of Crises & 50 & 42 & 47 & 47 & 47 & 20 & 43 & 47 \\
\hline $\mathrm{N}$ & 980 & 989 & 989 & 989 & 989 & 270 & 829 & 988 \\
\hline$\%$ crises correct & 68 & 67 & 66 & 66 & 66 & 75 & 67 & 68 \\
\hline$\%$ correct & 71 & 77 & 74 & 72 & 73 & 76 & 69 & 73 \\
\hline Pseudo $\mathrm{R}^{2}$ & 0.1180 & 0.1175 & 0.1139 & 0.1108 & 0.1135 & 0.2520 & 0.1146 & 0.1152 \\
\hline
\end{tabular}

$* * *, * *$, and $*$ indicate statistical significance at 1,5 , and 10 percent, respectively. 


\section{Table 4. Banking Crisis, Regulations, Institutions, and Concentration}

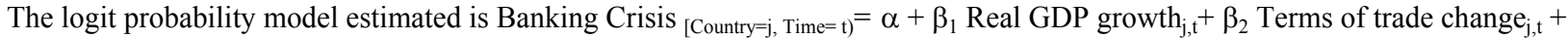
$\beta_{3}$ Real interest rate $\mathrm{j}_{\mathrm{j}, \mathrm{t}}+\beta_{4}$ Inflation $_{\mathrm{j}, \mathrm{t}}+\beta_{5} \mathrm{M} 2$ reserves $_{\mathrm{j}, \mathrm{t}}+\beta_{6}$ Depreciation $_{\mathrm{j}, \mathrm{t}}+\beta_{7}$ Credit growth $_{\mathrm{j}, \mathrm{t}-\mathrm{2}}+\beta_{8}$ Moral Hazard Index $_{\mathrm{j}, \mathrm{t}}+\beta_{9}$ Concentration $_{\mathrm{j}, \mathrm{t}}+\beta_{10}$ Regulatory measures $\mathrm{j}_{\mathrm{j}, \mathrm{t}}+\varepsilon_{\mathrm{j}, \mathrm{t}}$. The dependent variable is a crisis dummy that takes on the value of one if there is a systemic and the value of zero otherwise. Growth is the rate of growth of real GDP. Terms of trade equals the change in the terms of trade of goods and services. Real interest rate is the nominal interest rate minus the contemporaneous rate of inflation. Inflation is the rate of change of the GDP deflator. M2/reserves is the ratio of M2 to international reserves. Credit growth is the real growth of domestic credit, lagged two periods. Depreciation is the rate of change of the exchange rate. Moral hazard is an aggregate index of moral hazard associated with varying deposit insurance schemes. The aforementioned variables are used in analysis but not shown for the sake of brevity. Concentration is calculated as the fraction of assets held by the three largest banks in each country, averaged over the sample period. Bank data are from the Bankscope database of Fitch IBCA. Fraction of entry applications denied measures the number of entry applications denied as a fraction of the total applications received. Activity restrictions measures the degree to which banks are restricted from engaging in business of securities underwriting, insurance underwriting and selling, and from real estate investment, management, and development. Required reserves is the percentage of reserves regulators require banks to hold. Capital regulatory index is a summary measure of capital stringency. Banking freedom is an indicator of the relative openness of the banking system. Economic freedom is a composite measure of institutional factors determining economic freedom. KKZ_composite is a composite measure of governance indicators. White's heteroskedasticity consistent standard errors are given in parentheses. Detailed variable definitions and sources are given in the data appendix, available on request.

\begin{tabular}{|c|c|c|c|c|c|c|c|c|}
\hline & (1) & (2) & (3) & (4) & (5) & (6) & (7) & (8) \\
\hline Concentration & $-0.0402 *$ & $-0.0388 *$ & $-0.0492 * *$ & $-0.0483 * *$ & $-0.0568 * *$ & $-0.0584 * *$ & $-0.0523 * *$ & $-0.0564 * *$ \\
\hline & $(0.0211)$ & $(0.0211)$ & $(0.0246)$ & $(0.0224)$ & $(0.0253)$ & $(0.0267)$ & $(0.0243)$ & $(0.0249)$ \\
\hline \multicolumn{9}{|l|}{ Fraction of Entry } \\
\hline Applications & $\begin{array}{c}0.0345^{* * *} \\
(0.0127)\end{array}$ & & & & & & & \\
\hline Activity Restrictions & & $\begin{array}{c}0.0037 * * \\
(0.0014)\end{array}$ & & & & & & \\
\hline Required Reserves & & & $\begin{array}{c}0.0003 \\
(0.0003)\end{array}$ & & & & & \\
\hline Capital Regulatory Index & & & & $\begin{array}{l}-0.0016 \\
(0.0027)\end{array}$ & & & & \\
\hline Banking Freedom & & & & & $\begin{array}{c}-0.0164 * * * \\
(0.0058)\end{array}$ & & & $\begin{array}{c}-0.0121 * \\
(0.0071)\end{array}$ \\
\hline Economic Freedom & & & & & & $\begin{array}{c}-0.0185 * * \\
(0.0081)\end{array}$ & & \\
\hline KKZ_composite & & & & & & & $\begin{array}{c}-0.0153 * * \\
(0.0067)\end{array}$ & $\begin{array}{l}-0.0100 \\
(0.0084)\end{array}$ \\
\hline No. of Crises & 21 & 34 & 27 & 33 & 47 & 47 & 47 & 47 \\
\hline No. of Observations & 583 & 767 & 572 & 755 & 955 & 955 & 989 & 955 \\
\hline$\%$ crises correct & 67 & 74 & 67 & 70 & 68 & 66 & 68 & 70 \\
\hline$\%$ correct & 77 & 75 & 78 & 73 & 69 & 70 & 72 & 69 \\
\hline Pseudo $\mathrm{R}^{2}$ & 0.1854 & 0.2105 & 0.2477 & 0.2031 & 0.1145 & 0.1058 & 0.1106 & 0.1186 \\
\hline
\end{tabular}

***,**, and * indicate statistical significance at 1,5 , and 10 percent, respectively. 


\section{Table 5. Banking Crisis, National Characteristics, and Concentration}

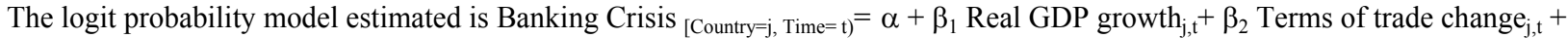
$\beta_{3}$ Real interest rate ${ }_{\mathrm{j}, \mathrm{t}}+\beta_{4}$ Inflation $_{\mathrm{j}, \mathrm{t}}+\beta_{5} \mathrm{M} 2 /$ reserves $_{\mathrm{j}, \mathrm{t}}+\beta_{6}$ Depreciation $_{\mathrm{j}, \mathrm{t}}+\beta_{7}$ Credit growth $_{\mathrm{j}, \mathrm{t}-2}+\beta_{8}$ Moral hazard index $_{\mathrm{j}, \mathrm{t}}+\beta_{9}$ Concentration $_{\mathrm{j}, \mathrm{t}}+\beta_{10}$ Historical Determinants $_{\mathrm{t}}+\varepsilon_{\mathrm{j}, \mathrm{t}}$. The dependent variable is a crisis dummy that takes on the value of one if there is a systemic and the value of zero otherwise. Growth is the rate of growth of real GDP. Terms of trade equals the change in the terms of trade of goods and services. Real interest rate is the nominal interest rate minus the contemporaneous rate of inflation. Inflation is the rate of change of the GDP deflator. M2/reserves is the ratio of M2 to international reserves. Credit growth is the real growth of domestic credit, lagged two periods. Depreciation is the rate of change of the exchange rate. Moral hazard is an aggregate index of moral hazard associated with varying deposit insurance schemes. The aforementioned variables are used in analysis but not shown for the sake of brevity. Concentration is calculated as the fraction of assets held by the three largest banks in each country, averaged over the sample period. Bank data are from the Bankscope database of Fitch IBCA. Legal origin includes the three dummies UK, France and Germany, which take the value 1 for each legal origin respectively. Latitude is the absolute value of the latitude of each country normalized to lie between zero and one. Religion includes three variables, Catholic, Muslim, Protestant which indicate the percentage of the population that follows a particular religion. Ethnic Fractionalization is the probability that two randomly selected individuals in a country will not speak the same language. White's heteroskedasticity consistent standard errors are given in parentheses. Detailed variable definitions and sources are given in the data appendix, available on request.

\begin{tabular}{|c|c|c|c|c|c|}
\hline & (1) & (2) & (3) & (4) & (5) \\
\hline Concentration & $\begin{array}{c}-0.0737 * * * \\
(0.0257)\end{array}$ & $\begin{array}{c}-0.0523 * * \\
(0.0242)\end{array}$ & $\begin{array}{c}-0.0789 * * * \\
(0.0248)\end{array}$ & $\begin{array}{c}-0.0579 * * \\
(0.0270)\end{array}$ & $\begin{array}{c}-0.0845^{* * *} * \\
(0.0246)\end{array}$ \\
\hline Common Legal Origin & $\begin{array}{c}-.0504 * * \\
(0.0211)\end{array}$ & & & & $\begin{array}{c}-0.0643^{*} \\
(0.0384)\end{array}$ \\
\hline French Legal Origin & $\begin{array}{l}-.0811 * * \\
(0.0338)\end{array}$ & & & & $\begin{array}{l}-0.0854 \\
(0.0722)\end{array}$ \\
\hline German Legal Origin & $\begin{array}{c}-.0289 * * * \\
(0.0084)\end{array}$ & & & & $\begin{array}{c}-.0318 * * * \\
(0.0086)\end{array}$ \\
\hline Latitude & & $\begin{array}{c}-0.0444 \\
(0.0350)\end{array}$ & & & $\begin{array}{l}-.0831 * * \\
(0.0332)\end{array}$ \\
\hline Catholic & & & $\begin{array}{c}-.0004 * * \\
(0.0002)\end{array}$ & & $\begin{array}{l}-0.000 * \\
(0.0002)\end{array}$ \\
\hline Muslim & & & $\begin{array}{l}-0.0001 \\
(0.0002)\end{array}$ & & $\begin{array}{c}0.0000 \\
(0.0002)\end{array}$ \\
\hline Protestant & & & $\begin{array}{c}0.0001 \\
(0.0003)\end{array}$ & & $\begin{array}{l}-0.0002 \\
(0.0004)\end{array}$ \\
\hline Ethnic Fractionalization & & & & $\begin{array}{c}0.0184 \\
(0.0197)\end{array}$ & $\begin{array}{l}-0.0036 \\
(0.0181)\end{array}$ \\
\hline No. of Crises & 47 & 47 & 47 & 47 & 47 \\
\hline No. of Observations & 989 & 989 & 989 & 974 & 974 \\
\hline$\%$ crises correct & 64 & 70 & 68 & 68 & 72 \\
\hline$\%$ correct & 71 & 74 & 72 & 73 & 71 \\
\hline Pseudo $\mathrm{R}^{2}$ & 0.1318 & 0.1174 & 0.1339 & 0.1147 & 0.1583 \\
\hline
\end{tabular}

***,**, and * indicate statistical significance at 1,5 , and 10 percent, respectively. 